\title{
JUDICIAL INDEPENDENCE AND JUDICIAL Administration: The Case of Provincial COURT Judges
}

\section{Carl Baar}

The object of this paper is to consider the independence and impartiality of Provincial Court judges in Canada in relation to court administration, as distinct from judicial selection, compensation and discipline. This still leaves an unwieldy variety of important issues: executive versus judicial control of court administration (where are we seventeen years after Chief Justice Jules Deschênes recommended that provincial governments move beyond the old system of departmental control?); ${ }^{1}$ delay reduction (where are we eight years after Askov?); ${ }^{2}$ the rise of caseflow management and AD R (who controls cou rt calendars?); and the role of the chief judge (especially in light of the questions raised by Justice D avid Marshall). ${ }^{3}$

This paper will focus on the issue of trial court organization and its relations hip to the independence of Provincial Court judges. Over the past two decades, the most controversial issue in this subfield of court administration has been the proposal for a unified criminal court - replacing the separate Provincial Courts and superior courts with a single judicial tribunal and single class of judge to hear all criminal matters. The proposal has been championed by Provincial Court judges, primarily through their national association, and been opposed by section 96 judges, not only through their national association (the Canadian Judges Conference) but also by the Canadian Judicial Council (which has no representation from chief judges appointed by provincial governments) and the Canadian Bar Association.

The conflict over the unified criminal court has often been interpreted in terms of the competition for status within the judiciary (with ProvincialCourt judges seeking added status — and salary — and superior court judges anxious to ma intain their status), in spite of efforts by advoc ates on bo th sides to articu late public

Jules D eschê nes, Maître chez eux/Mas ters in Their Own House (Ottawa: C anadian Jud icial Council, 1981).

Regina v. Askov et al. [1990] 2 S.C.R. 1199.

3 T. David Marshall, Judicial Cond uct and Accountability (Toronto: C arswell, 1995). interest argumen ts to support their positions. One of the reasons for this pejorative interpretation is that the unified criminal court concept has not raised fundamental issues of judicial independence. Superior court judges have not alleged that unification would undermine judicialinde-pendence, even after provincial attorneys-general unanimously endorsed the principle. Conversely, Provincial Courtjudges have never argued that the existing two-level system, whatever its failings, undermined judicial independence. In practice, criminal court unification could have been a valuable reform in some jurisdictions, but would have had little impact in others, and it is unfortunate that the polarized debate has allowed opponen ts to forestall its implementation even where it makes sense. ${ }^{4}$

More recently, important issues of trial court organization have arisen when efforts have been made to expand the role of subordinate judicial officers (for example, justices of the peace and small claims adjudicators). Critics fear that provincial governm ents are sacrificing justice to save money, and perhaps even reintroducing a new third tier of trial courts. These debates have been intermittent, particularistic, and largely below public consciousness. However, they intensified in Alberta following the introduction of Bill 25, the Justice Statutes Amendment Act, 1998. ${ }^{5}$ The issues raised by Bill 25 about the expanded role of justices of the peace in criminal cases are not unique to

\footnotetext{
When my study, One Trial Cou rt: Possibilities and Limitations (Ottawa: Canadian Judicial Council, Nov. 1991) was commissioned by the Council (with financial support from the federal Departmen $t$ of Justice), Council members indicated that the report was to contain no recommendations. In fact, the Council express ed its ow $n$ official opinion with remark able haste once the report was tabled. Afterwards, one court of appeal judge sa id that it was the most balanced report I had ever written. It argued for more "integration" of trial courts (for example, through joint administration of criminal caseloads), and tried to dispell avariety of myths about the impact of cou rt reorganization. If the report had included recomm endations, they might have been summarized as "Court unification if neces sary, but not $\mathrm{n}$ ecessa rily cou rt unific ation."

2nd Session, 24th Legislature, Alb erta 1998, amended by
} Sessional Paper 605/98, 20 April 1998. 
Alberta, and it is the purpose of this paper to examine those issues - precisely because the design of courts and court processes to handle "routine" or "minor" matters is likely to raise questions of judicial independence.

This paper will argue that independence issues arise in trial court organization when designers attempt to separate out certain types of cases, because some kinds of adjudication are more dependent on executive branch support than others. (Here I am deliberately avoiding the more inflammatory term "government interference," because it has a specialized meaning that hides the many other ways that executive action can routinely shape the o utcome of adjudicatory processe s.) The paper draws on a typology of adjudication first developed in the mid-1980s to analyze the effects of court organization on trial court operations. ${ }^{6}$ It has subsequ ently been applied to appella te courts as well. ${ }^{7}$ That typology suggests that the nature of government involvement in court administration varies from one type of adjudication to another. As a result, independence concerns are more likely to arise in dealing with some adjudicatory processes than with others - in particular, those that increasingly frugal provincial governments hope to shift to non-judges.

\section{Three ADJUdicatory PROCESSES}

If we were to ask law professors orjudges to define or characterize adjudication, they would focus on elements of the adversary system: an impartial judge who is essentially passive, absorbing the arguments made by contending counsel in a formal atmosphere conducive to deliberating, making findings of facts and drawing conclusions of law. This is a way of performing tasks that the late organization theorist James Thompson labeled a mediating technology. ${ }^{8} \mathrm{He}$ argued that this technology, or method of getting work done, was different from the way work is done in most other organizations. Thompson provided a firm foundation in management theory for what all of us know: that courts are not like other organizations, and governments that try to apply to courts solutions that

6 C.M. Kerwin, T.A. Henderson and C. Baar, "Adjudicatory Processes and the Organization of Trial Courts" (1986) 70 Judicature 99-106. For the full study, see T.A. Henderson et al., The Significance of Judicial Structure: The Effects of Unification on Trial Court Operations (Washington, D.C.:U.S. Departmen $t$ of Justice, Nationa 1 Institute of Justice, 1984).

7 C. Baar and E. Baar, "Diagnostic Adjudication in Appellate Courts: The Supreme Court of Canada and the Charter of Rights" (1989) 27 Osgoode Hall Law Journal 1-25.

8 J.D. T hom pson, Orga nizations in Action: Social Science Bases of Administrative Theory (New York: McG raw-Hill, 1967). For a current similar analysis by Canada's leading management theorist, see H. Mintzberg, "Managing Government: Governing Management" (1996) Harvard Business Review 75-83. may have succeeded in other organizations will be sorely and deservedly disappointed. ${ }^{9}$

Even this view of a djudication fails to capture the wide range of real-life adjudication that takes place every day in our courts. Litigants often appear without counsel. Judges cannot be passive; they have to ask questions and elicit responses. Deliberation is minimal, often because the issue is not in dispute or the re sult is expected by and known to participants; in this setting, judges rule quickly on matters that require their review and authorization. Here we think of criminal intake court, bail reviews, traffic court, and many summary conviction and even indictable proceedings; motions court and set-date court in civil proceedings; routine proceedings in family court; and leave applications and many sentence appeals in appellate courts.

These activities are all adjudication, even though they often lack the calm and clean liness we a ssociate with the classic adversary proceeding. Even if trial courts were reorganized into a one-level structure, this kind of adjudication would persist, coexisting alongside the first, more deliberative adversarial style, because some tasks are more routine and predictable than others - and even require speed in order to ensure fairness. The first type has been labelled procedural adjudication, for the traditional full-dress adversary hearing $w$ ith its emphas is on procedural completeness. The second has been called decisional adjudication, for the rapid-fire case processing of the active judge with its emphasis on getting the decisions made. 
There is also a third type of adjudication distinct in theory and practice from the other two, observable every day in Canadian trial courts. It can be termed diagnostic adjudication, because it focuses more on solving problems than on resolving specific disputes or making specific decisions. Many family court proceedings, whether they involve unrepresented litigants or those with counsel, are diagnostic in nature. The judge is often active, but intervenes more to find a solution to a problem than an answer to a legal question. One of the original bases for a separate Juvenile Court was that the adjudication of charges against young offenders should be conducted differently — that diagnostic adjudication should replace the decisional adjudication that often dominates adult criminal courts. In turn, the Young Offenders Act reflected a concern for more formality and legality — an attempt to shift from diagnostic to procedural adjudication.

While the tasks that require procedural and decisional adjudication tend to be stable over time, the tasks that require diagnostic adjudication often change. Some family court business becomes so routinized that those tribunals come to be dominated by decisional adjudication, just as the work of equity courts (a famous historical attempt to move away from the legalism of common law procedural adjudication in order to solve problems) became routinized in subseque nt centuries. C onversely, diagnostic adjudica-tion can become so formalized that problem-solving gives way to an elaborated fact-finding process dominated by lawyers, taking on the character of procedural adjudication. Opponents of establishing unified family courts at the superior court level have been concerned with this possibility.

Thompson's theoretical writings on organizational technology can be seen in all three adjudicatory processes. He not only identified mediating technology (corresponding to procedural adjudication), where the emphas is is on defining the relationship between two parties; he also discussed long-link technology, with its emphas is on the relationship between sequential tasks (corresponding to decisional adjudication), and intensive technology, exemplified by the doctor's tasks of diagnos is and treatm ent.

\section{Designing Trial CoURTS AROUND ADJUDICATORY PROCESSES}

The existence and persistence of three distinct adjudicatory processes is one of the reasons for the temptation to differentiate between courts and between judges. Procedural adjudication has the highest status; it approximates the purest form or ideal type of adjudication, and combining it with a large dose of decisional or diagnostic adjudication would, by this argument, dilute the quality of the work.
This temptation reached its zenith in the English courts. Magistrate's Courts, staffed largely by unpaid lay judges, do the criminal intake work and try minor offences. When legal issues arise, there are law-trained clerks to assist them. Family law matters involving women and children as distinct from the division of property were also given to magistrates, reinforcing through class bias the distinction between diagnostic and procedura 1 adjudication. The Magistrate's Courts have been administered until very recently by the Home Office rather than the Lord Chancellor's D epartment, emphasizing their role as a link in the law enforcement process rather than their status as independent adjudicators. In 1990, when I asked a senior judge in a modern London Crown Court about Canadian proposals to create a one-level criminal court, he wondered in amazement why we would have our "best minds working on garbag e."

Even if a trial court is unified, so that its work includes tasks that require all three types of adjudication, different types of judges are created or assigned to handle decisional and diagnostic adjudication. The District of Columbia Su perior Court continues to expand the number and jurisdiction of its commissioners - in small claims, criminal intake, and landlord-tenant matters. Connecticut's one-level trial court has geographic area courts to supplement its judicial district courts, Illinois has Associate Circuit Judges to assist its Circuit Judges, and South Dakota has "law-trained magistrates" for the same purpose. The Family Court of Australia, distinctive because it is a commonwealth (i. e. federal) unified family court, has developed a set of subordinate judicial officers to handle a variety of proceedings deemed routine. ${ }^{10}$

Minne sota has gone furthe $r$ in implementing a onelevel trial court with one class of judicial officers performing a full share of all three adjudicatory processes. I watched one Minneapolis judge leav e a bail hearing for her chambers in order to meet a roomful of lawyers for a motion in a complex civil suit that was part of her 300-case "civil block"; the previous month, she did her semi-annual tour of duty in a suburban strip mall. Even in that system, however, Minneapolis developed a cadre of family law commissioners, and St. Paul had one judge dealing exclusively with Juvenile Court matters.

In Canada, the province that has most fully embraced the notion that ev ery judge should engage in all three adjudicatory processes is New Brunswick. Early provincial efforts to create a unified criminal court at the Provincial Court level were held

\footnotetext{
10 Examples in this section are drawn from research for One Trial Court, supra note 4.
} 
unconstitutional by the Supreme Court of Canada, ${ }^{11}$ although the New Brunswick Court of Appeal detected no such constitutional prohibition when it considered the matter. ${ }^{12}$ Later, the provincial govern ment tried to unify criminal matters in the Court of Queen's Bench, and had the support of the Q.B. Chief Justice. Those efforts were derailed after federal Justice Minister Alan Rock's unprecedented undertaking that federal authorization (by amending the Judges $A c t^{13}$ ) would require superior court and provincial bar endorsement of the proposal.

Throughout this time, New Brunswick Provincial Court judges functioned without the presence of either sitting or signing justices of the peace, the one province in Canada where on ly a judge can sign a ben ch warran $t$. And since New Brunswick's superior court judges hear a lower proportion of indictable offences than most other provinces, its Provincial Court judges conduct a substantial am ount of proc edural adju dication as w ell.

Meanwhile, Court of Queen's Bench justices were required a decade ago by a reforming Attomey General to take over all civil claims, including small claims that had been heard for many years by law-trained registrars. Thus judges with listening skills honed by years of procedural adjudication were required to intervene when unrepresented plaintiffs either omitted or embellished the facts of their civil claims. One experienced judge was con vinced that the added variety of work imp roved his colleagues' performance in their traditional cases. But the results for the clients of small claims court were mixed at best. The informality of registrar's hearings had in the past allowed unrepresented litigants to go home to pick up needed documents, and appeals had gone to a single Que en's Bench judge in the same community, not the Court of Appeal in the provinc ial capitol.

It may be preferable for a court and its judges to have a rich mix of adjudicatory processes, but in a large court, there will be enough routine litigation to generate substantialpressure to create a new clas s of subord inate judicial officers. To the extent that a growing volume and variety of cases can be handled in standardized ways, the use of decisional adjudication is likely to grow, along with an expansion of the responsibilities of subordinate judicial officers. If so, however, what are the policy implications? What is the desirable mix of adjudication, not only for the quality of justice, but also for the independence of the judiciary?

11 McEvoy v. Attorney General of New Brunswick and Attorney General of Canada, [1983] 1 S.C.R. 704.

12 Reference Re Establishment of a Unified Criminal Court of New Brunswick (1981), 62 C.C.C. (2d) 165.

13 R.S.C. 1985 , c. J-1.

\section{JUDICIAL INDEPENDENCE AND ADJUDICATORY PROCESSES}

How does the typology of adjudicatory processes relate to issues of judicial independen ce? Don't judges require individual independence — impartiality regardless of what type of adjudication they are doing? The answer clearly is yes. Even the most routine matters require the independence of the person responding to the request or assertion or claim. If not, those matters might as well be shifted outside the court.

It is when we turn to institutional independence that variations can be observed in the degree to which different adjudicatory processes are independent. Procedural adjudication is the most independent of government for the institutional resources it requires. Impartial adjudication requires an informed judge; to become informed, the judge can request that counsel brief an issue or argue a point. The "procedural judge" is thus less dependent on government to complete essential tasks in a wide range of cases in which priv ate counsel can function as officers of the court. Governments can produce inconvenience, as in the metaphor of the judge without pencil and paper, but are less able to prevent the judiciary from doing its work or directly to affect outcomes.

Contrast this with diagnostic adjudication, where judges need the support and expertise of government personnel to decide individual cases. Civil servants often replace lawyers as the key "officers of the court." Thus a probation officer evaluates the individual needs of a young offender before the judge passes sentence. Social workers do assessments before custody decisions are made. Child protection personnel play essential roles in how a judge exercises discretion under provincial child welfare legislation. In the U.S., juvenile courts have taken on the character of integrated regulatory bodies, and the expansion of "drug courts" in which adults charged with narcotics offences are directed to treatment at first appearance, prior to any determination of guilt or innocence, has produced a level of interdependence between judiciary and law enforcement that raises new questions about the independence of adjudication. 
And in decisional adjudication, ordinary administrative functions take on a critical role. Managing the flow of high-volume cases is intim ately connected to their outcome and to the use of the court itself. For example, the impartiality of decisional adjudication is directly linked not only to the judge, but to the timing of the proceedings. A long wait for a small matter makes the cost prohibitive. The extra days before reaching a bail hearing preempt the judicial function itself. It should be no surprise that Malcolm Feeley titled his study of decisional adjudication The Process Is the Punishment. ${ }^{14}$

Current provincial policies may be increasing the proportion of diagnostic and decisional adjudication. Legal aid cutbacks have increased the number of unrepresented litigants in Canadian courts, making judges more dependent on administrative staff for everything from maintaining order in the courtroom, providing directions in the courthouse, and giving advice at the counter. Failure to fill judicial vacancies or recognize the need for additional judgeships generates pressure to conform to formulas that accelerate decisions by making them more me chanical; see, for example, proposals to use standard form factums in sentence appeals.

Once decisional adjudication comes to dominate a class of cases, and policym akers (or judges themselves) shift these tasks to a new class of subordinate judicial officers such as justices of the peace, the maintenance of individual independence becomes problematic. If government has the discretion to appoint these adjudicators, it can set qualifications below those of existing judges, enlarge the pool, and increase the opportunity for other agendas (such as loyalty to the party in power) to come into play. If the judiciary tries to counteract this tendency by taking on a larger role in appointment and supervision of these judicial officers, individual independence may still be problematic if the new adjudicators feel the approval of their judicial superiors is necessary for continuation in office or elevation to a judgeship.

In diagnostic adjudication, the role of subordinate judicial officer is often filled by a mediator sometimes full-time, other times part-time. As mediation expands to cover a full range of civil litigation traditionally dominated by procedural adjudication, new questions are likely to arise about how mediators are appointed and what roles they play in the process.

14 M. Fe eley, The Process Is the Punis hment: Hand ling Ca ses in a Lower Crim inal Court (New York: Russell Sage Foundation, 1979).
In summary, decisional and diagnostic adjudication require more extensive managerial and professional staff support than procedural adjudication, where the judge can more effectively rely on counsel for the support required for independent and impartial adjudication. It should not be surprising, then, that changes in court organization that have a high impact on decisional and diagnostic adjudicationgenerate more concern about judicial independence.

This analysis should not lead readers to be complacent about the institutional independence of judges and courts dominated by procedural adjudication. A chief jud ge willing to w ield assignment power to promote particular outcomes favourable to the government in power can undermine judicial independence in any court. Thus, during the later years of the apartheid regime in South Africa, a chief justice loyal to the regime was given the authority under the emergency laws to designate which jud ges on his court were eligible to try persons accused under those laws. ${ }^{15}$ Lest it be assumed that this sort of indirect manipulation of the judiciary by govern ment is unique to undemocratic one-party states, note that U.S. President Richard Nixon's 1970 wage and price control legislation established a Temp orary Emergenc y Court of Appeals, with a cadre of federal judges designated by Chief Justice Warren Burger, so that no otherjudge in the federal court system could rule on the constitutionality of any action taken under the legislation. The power of chief judges was one of the underlying issues in last year's Tobiass case, in which the Supreme Court of Canada held that a meeting between a government lawyer and a Chief Justice to accelerate a war crimes proceeding violated the individual independence (impartiality) of the trial judge. ${ }^{16}$

\section{AINTAINING INDEPENDENCE W HILE DIVIDING WORK}

This paper has argued that the seemingly inexorable rebirth of subordinate judicial officers in Canadian trial courts is linked to the continued and perhaps growing importance of decisional and diagnostic adjudication, and because thos e adjudicatory processes require more extensive and intrusive government

\footnotetext{
15 D. Dyzenhaus, "Telling the Truth about Law: South Africa's Truth and Reconciliation Commission Inquiries into the Aparth eid Legal Order" unpublished paper (Faculty of Law, University of T oronto, 19 Jan uary 1998 ).

16 Canada (Minister of Citizenship and Immigration) v. Tobiass, [1997] 3 S.C.R. 391. And see C. Baar, "Judicial Independence and Judicial Administration in the Tobiass Case" (1998) 9 Constitutional Forum 48-54.
} 
support, questions of judicial independence are more likely to arise.

Given this analysis, what should policymakers do as they redesign courts with a high volume or high proportion of decisional and diagnostic adjudication?

First, avoid hiving off this work to a separate co urt. A new class of judicial officers - or existing judicial officers with expanded roles - should be doing their work within an existing fully independent court. Otherwise, the opportunity for the court to be captured by its clientele becomes too great, and scheduling of cases and courtrooms too susceptible to government agendas. For example, early in the 1990s lay justices of the peace in Toronto received night court assignme nts from a court administrative official, and believed that this extra work (with its extra pay) went to those more likely to generate fine income for the province.

Second, ensure that work now done by independent judges is not shifted to judicial officers who are less independent. Even routine and repetitive tasks are brought before independent judges because their review is considered essential to preserve private rights. If this is not the case, those tasks should be shifted outside the court, to an administrative agency or to the private sector. This principle also means that while judicial decisions made by subordinate judicial officers should be subject to appeal, the y should not require sign-off by a judge, as is the practice for some functions performed by court commissioners in the District of Columbia Superior C ourt.

Third, avoid granting legislative discretion in matters of judicial administration to a provincial cabinet or a provincial cabinet minister. Governments must be prepared either to spell out policy in legislation, or to delegate authority to the judiciary. Flexibility is a benefit of delegation, but flexibility for governm ent in the design of courts and the management of adjudication generates suspicions and concerns that undermine effectiveness and detract from both the independence and accountability of the judiciary.

Fourth, do not confuse specialized judges with specialized courts. Judges with particular skills or expertise may be valuable in all three adjudicatory processes, but they should not be permanen tly assigned to a single area. For example, unified family courts benefit from specialized judges, but are more effective as divisions of a larger court, so that judges ready for other work need not go to the government for a new appointment, but to a chief judge or committee of judges for a new assignment.

Fifth, encourage courts to address issues of governance. In the past, institutional independence required delegation of authority to a chief judge, without any framework for exercising the authority consistent with the collegial nature of courts and an appropriate degree of autonomy for individual judges. In the past generation, Provincial Courts have been consolidated and internally differentiated, that is, they are both larger and more diverse. Internal govemance should reflect these changes.

Sixth, give special consideration to appropriate and publicly defensible criteria for the selection of subordina te judicial officers, and develop processes for both appointment and elevation. An appointment body that makes limited recommendations (for example, a short list of no more than three) is preferable to a screening body that simply adds to a long list from which government can choose. Strong merit criteria will enhance respect for judicial officers whose wo rk is dominated by low status adjudication, as will recognition of the diverse population those judicial officers will serve. Thus selection criteria should be developed that emphasize skills and understanding needed for decisional and diagnostic adjudication.

If strong can didates are se lected, they a re likely to prove suitable for elevation to a judgeship, so processes should be considered in advance to ensure that fair evaluation of candidates for elevation takes place.

The emphasis on merit will have little meaning unless the nominating body itself is at arms' length from government, and draws its members from key constituencies including, for example, the bench, bar and public. One interesting model has operated for some years in the state of Illinois, where Associate Circuit Judges are "elected" by the Circuit Judges themselves, following a survey administered by the state bar asking for views on the candidates from all lawyers in the circuit. Results are reported in statistical form to the judges. The quality of A ssociate Circuit Judges has been high enou gh that when a Circu it Court vacancy occurs, the A ssociates make cre dible candidates, and limit the influence of politicians plumping for personal favourites.

\section{FROM "PROVINCE BUILDING" TO THE DECONSTRUCTION OF PROVINCIAL COURTS}

An expansion of the role of justices of the peace in Alberta would parallel developments and plans in other provinces. In British Columbia, the Provincial Court has been interested in the appointment of law-trained referees to do civil pretrials. For many years, both Nova Scotia and On tario have used a network of ad hoc sm all claims court judges that largely would fail the six criteria noted above. 
In 1997, the Ontario Government introduced legislation (Bill $108^{17}$ ) to shift the administration of the Provincial Offences Court to the municipalities, a reversal of every change in the administration of Provincial Courts in the past 30 years. Under the bill, municipalities would ab sorb the costs but also gain the benefits: they would keep all traffic as well as parking fines. The legislation was careful to ensure that the lay justices of the peace who sit as Provincial Offences Court judges would remain under the direction of the Office of the Chief Judge of the Provincial Court, and that municipalities understand the importance of independent adjudication. But municipal admin istration is likely to produce uneven enforcement of fines, and could therefore bring the administration of justice in traffic cases into disrepute even with independent judges - a reminder of the extent to which the quality of decisional adjudication is dependent on government action.

The neoconservative agenda of the Ontario and Alberta provincial governments is not the explanation for what appears to be the deconstruction of Provincial Courts in the $1990 \mathrm{~s}$. For some time, Ontario's NDP Government actually entertained the notion of appointing lay judges to hear small claims - even after the smallclaims limit was raised to $\$ 6,000$. It is unclear whether cooler heads prevailed or whether the reform was lost in a queue in that government's unwieldy legislative screening process.

Taken together, thes e developments would shift matters that use decisional and diagn ostic adjudication further from the core of Provincial Court work. To the extent that these changes result in a more mechanistic uniformity in place of increasing professionalism and collegiality, what will emerge may fit one of the models defined in a study of court reorganization in the United States. ${ }^{18}$ The authors discussed how some American state courts approximated a franchise model, with a host of procedural rules to ensure uniformity, but without the discretion needed by an effective court. In short, said the auth ors, what you had were "Ken tucky Fried Co urts."

Canadian experience has been very different. Throughout the 1970 s and 1980 s, provincial governments were engaged in a process that political scien tists characterized as "province building." Y ears of effort upgrading the status of the Provincial Courts was part of this process, as Peter McCormick observed a decade

17 An Act to deal with prosecution of certain provincial offences, to reduce duplication and to streamline administration, $1 \mathrm{st}$ Session, 36th Legislature, Ontario, 1997.

18 C. Baar and T. Henderson, "Alternative Models for Organization of State Cou rt Systems" (1982) 10 Policy Studies Journal 756-67. ago in his pioneering study of provincial judicial councils. ${ }^{19}$ Canadian Provincial Courts today have more extensive jurisdiction than any court of limited jurisdiction in the U.S., the U.K. or Australia. Furthermore, Provincial Court judges throughout Canada handle an increasingly higher proportion of serious criminal matters. ${ }^{20}$

However, too many current reforms move in an opposite direction. They confuse simple solutions with simplicity of design, cost-cutting with reducing the cost of litigation, reducin $g$ debt with increasing public trust, and downsizing with promoting accessibility. Designing courts with less prestige and appointing subordina te judges with less independence will not produce real benefits for the government or the public.

Instead, it is essential that initiatives to handle lowdollar civil cases and low-penalty criminal cases be (and be seen as) the newest developments in the evolution of a stronger, more effective and more independent Provincial Court - as reconstruction, not deconstruction. This will require a joint effort on the part of the judiciary and government policymakers, so that the outcome will be greater public respect for the court and the rule of law.

\section{Carl Baar}

Department of Politics, Brock University. Prepared for delivery at a Symposium on "Independence and Impartiality: The Case of Provincial Court Judges," Centre for Constitutional Studies, University of Alberta, 21 April 1998. 